\section{Persistence of intrasellar trigeminal artery and simultaneous pituitary adenoma: description of two cases and their importance for the differential diagnosis of sellar lesions}

\author{
Persistência da artéria trigeminal intrasselar e simultâneo \\ adenoma de hipófise: descrição de dois casos e importância \\ para o diagnóstico diferencial das lesões selares
}

Marcio Carlos Machado', Sergio Kodaira², Nina Rosa Castro Musolino

\section{SUMMARY}

Persistent trigeminal artery (PTA) is the most frequent embryonic communication between the carotid and vertebrobasilar systems. However, hormonal changes or the association of PTA with other sellar lesions, such as pituitary adenomas, are extremely rare. The aim of the present study was to report two patients with intrasellar PTA and simultaneous pituitary adenoma in order to emphasize the importance of differential diagnoses for sellar lesions. Case 1. A female patient, 41 years old, was admitted with a history of chronic headache ( $>20$ years). Pituitary magnetic resonance imaging (MRI) showed a rounded lesion in the left portion of the pituitary gland suggestive of adenoma (most likely clinically non-functioning adenoma). In addition to this lesion, the MRI demonstrated ecstasy of the right internal carotid artery and imaging suggestive of an intrasellar artery that was subsequently confirmed by an angio-MRI of the cerebral vessels as PTA. Case 2. A female patient, 42 years old, was admitted with a history of amenorrhea and galactorrhea in 1994. Laboratorial investigation revealed hyperprolactinemia. Pituitary MRI showed a small hyposignal area in the anterior portion of pituitary gland suggestive of a microadenoma initiated by a dopaminergic agonist. Upon follow-up, aside from the first lesion, the MRI showed a well delineated rounded lesion inside the pituitary gland, similar to a vessel. Angio-MRI confirmed a left primitive PTA. Failure to recognize these anomalous vessels within the sella might lead to serious complications during transsphenoidal surgery. Therefore, although their occurrence is uncommon, a working knowledge of vascular lesions in the sella turcica or pituitary gland is important for the differential diagnosis of pituitary lesions, especially pituitary adenomas. Arq Bras Endocrinol Metab. 2014;58(6):661-5

\section{SUMÁRIO}

Persistência da artéria trigeminal (PAT) é a comunicação embrionária mais frequente entre os sistemas carotídeo e vertebrobasilar. No entanto, alterações hormonais ou associação de PAT com outras lesões selares, como adenomas hipofisários, são extremamente raros. 0 objetivo do presente estudo foi relatar dois pacientes com PAT intrasselar e concomitante adenoma hipofisário e enfatizar a importância para o diagnóstico diferencial de lesões selares. Caso 1. Paciente do sexo feminino, 41 anos, admitida com história de cefaleia crônica (> 20 anos). Ressonância magnética (RM) de hipófise mostrou imagem arredondada na porção esquerda da glândula sugestiva de adenoma (provavelmente adenoma clinicamente não funcionante). Adicionalmente, a RM demonstrou ectasia da artéria carótida interna direita e imagem sugestiva de artéria intrasselar, posteriormente confirmada por angio-RM dos vasos cerebrais como PAT. Caso 2. Paciente do sexo feminino, 42 anos, admitida com história de amenorreia e galactorreia em 1994. A investigação laboratorial revelou hiperprolactinemia. RM de hipófise mostrou pequena área de hipossinal na porção anterior da glândula sugestiva de microadenoma, sendo iniciado agonista dopaminérgico. $\mathrm{Na}$ evolução, além da primeira lesão, a RM mostrou uma imagem arredondada bem delimitada dentro da glândula pituitária semelhante a vaso sanguíneo. Angio-RM confirmou PAT primitiva esquerda. A falta de reconhecimento de tais vasos anômalos dentro da sela túrcica pode levar a sérias complicações durante a cirurgia transesfenoidal. Portanto, apesar de sua ocorrência não ser comum, o conhecimento de lesões vasculares dentro da sela túrcica ou glândula hipofisária é importante para o diagnóstico diferencial de lesões da hipófise, especialmente com adenomas hipofisários. Arq Bras Endocrinol Metab. 2014;58(6):661-5
${ }^{1}$ Neuroendocrine Unit, Division of Endocrinology and Metabolism, University of Sao Paulo School of Medicine (FMUSP), Sao Paulo, SP, Brazil ${ }^{2}$ Department of Radiology, FMUSP, Sao Paulo, SP, Brazil ${ }^{3}$ Neuroendocrine Unit, Division of Neurosurgery, FMUSP, Sao Paulo, SP, Brazil

Correspondence to: Marcio Carlos Machado Neuroendocrine Unit Division of Endocrinology and Metabolism,

University of Sao Paulo School of Medicine

Av. Dr. Enéas de Carvalho Aguiar, $155,8^{\text {th }}$ floor

05403-060 - Sao Paulo, SP, Brazil marcioc-machado@uol.com.br

Received on Nov/14/2013 Accepted on May/30/2014

DOI: 10.1590/0004-2730000003363 


\section{INTRODUCTION}

$\mathrm{P}$ ersistent primitive carotid-basilar anastomoses are uncommon embryological vascular remnants (1). The most frequent anomalous embryonic communication between the carotid and vertebrobasilar systems is a persistent trigeminal artery (PTA). This vascular anomaly has been observed in $0.1-0.2 \%$ of cerebral angiograms, usually as an incidental finding (2).

Although the presence of PTAs is generally of uncertain significance, these arteries and their variants have been identified as a rare cause of cranial nerve dysfunction, including incomplete oculomotor nerve palsy, trigeminal neuralgia and hemifacial spasm (3-5) and sixth nerve palsy $(6,7)$.

The presence of hormonal alterations or the association of PTA with other sellar lesions, such as pituitary adenomas, is extremely rare. To the best of our knowledge, there are only five reported cases of association between PTA and concomitant pituitary adenoma (8-12).

The aim of the present study was to report two patients with intrasellar PTA and simultaneous pituitary adenoma, emphasizing the importance of sellar tumors in differential diagnoses.

\section{CASE REPORTS}

\section{Case 1}

In June 2007 , a female patient, 41 years of age, was admitted to the hospital with a history of chronic headache for more than 20 years. Her menarche occurred at 18 years of age, followed by irregular menses (spaniomenorrhea) that improved after oral contraceptive usage. In December 2006, she suffered an acute episode of headache associated with right ocular pain and submitted to a neurological evaluation and cranial CT imaging. At the physical exam, she presented no stigma or any other alterations. All initial exams (June 2007) were normal (glucose, $\mathrm{Na}, \mathrm{K}$, liver enzymes, renal function, total and ionic calcium and blood counts). Hormonal exams were also in the normal range (PRL: $8.3 \mathrm{ng} / \mathrm{mL}$, reference [R]: 2-15; LH: 2.7 IU/L; FSH: 2.8 IU/L; TSH: $2.3 \mu \mathrm{U} /$ mL, R: 0.4-4.5; FT4: 0.9 ng/dL, R: 0.7-1.5; serum cortisol $800 \mathrm{~h}: 8.1 \mu \mathrm{g} / \mathrm{dL}, \mathrm{R}: 5-25$; GH: $0.5 \mathrm{ng} / \mathrm{mL}$; and androgens) except for a small increase in the IGFl level (359 ng/mL, R: 101-267). In September 2007, the hormones were reassessed and again fell in normal ranges, including the IGFl level (PRL: $7.4 \mathrm{ng} / \mathrm{mL}$; serum cortisol 800 h: $11.5 \mu \mathrm{g} / \mathrm{dL}$; TSH: 2.6; FT4: 0.9; GH: 0.1 $\mathrm{ng} / \mathrm{mL}$; IGFl: $243 \mathrm{ng} / \mathrm{mL}$; and IGFBP3: $5.5 \mathrm{mg} / \mathrm{L}$, R: 3.3-6.6). Pituitary magnetic resonance imaging (MRI) (April 2007) showed a slight enlargement of the pituitary gland (height of $11 \mathrm{~mm}$ ) with a small lesion in the posterior and lateral left portion of pituitary gland that was $7 \mathrm{~mm}$ in diameter with a low signal in the T2 MRI sequence and a peripheral high signal in the $\mathrm{Tl}$. This lesion made contact with the optical chiasma was and deviated up and to the left, suggestive of pituitary adenoma (most likely non-functioning pituitary adenoma) (Figure 1B). In addition, the MRI demonstrated ecstasy of the right internal carotid artery and imaging suggestive of an intrasellar artery (Figures IA and IC) that were subsequently confirmed by angio-MRI of the cerebral vessels, such as PTA (Figure 1D). Neuro-ophthalmomologic tests, fundoscopy and computed visual field exams were normal. The following medications were prescribed for headache prophylaxis and achieved a partial response: amitriptyline $25 \mathrm{mg}$ /day and propranolol $40 \mathrm{mg}$ bid. In June 2009, the patient became pregnant after oral contraceptive withdrawal. The pregnancy proceeded normally, and the baby was born healthy and without abnormalities. After delivery and lactation, the patient began to experience normal menses once again, and a new hormonal evaluation revealed no alterations (including oral glucose tolerance test with $\mathrm{GH}$ measurements). The last pituitary MRI revealed the same dimensions as seen in PTA imaging and for the presumed adenoma.

\section{Case 2}

In December 2008, a female patient, 42 years of age, was admitted with a history of amenorrhea and galactorrhea in 1994. The patient was overweight, and the physical exam revealed bilateral galactorrhea (+/IV) but no signs of Cushing, acromegaly, hypothyroidism or other systemic disease. She denied any use of medications.

The laboratory investigations revealed slight hyperprolactinemia (PRL) $(39 \mathrm{ng} / \mathrm{mL}, \mathrm{R}: 2.1-18.1)$ but no other changes in the general and hormonal exams. Pituitary MRI showed a small Tl low signal area in the anterior and median portions of the pituitary gland suggestive of microadenoma, and a dopaminergic agonist was prescribed. Upon follow-up, her initial complains improved. Her menses returned to normal, and her galactorrhea disappeared. However, her weight gain persisted. In 2007, although good clinical control and the absence of collateral effects had been achieved, the dopaminergic agonist was changed to cabergoline $0.5 \mathrm{mg}$ / week before being reduced to $0.5 \mathrm{mg} /$ every two weeks. 

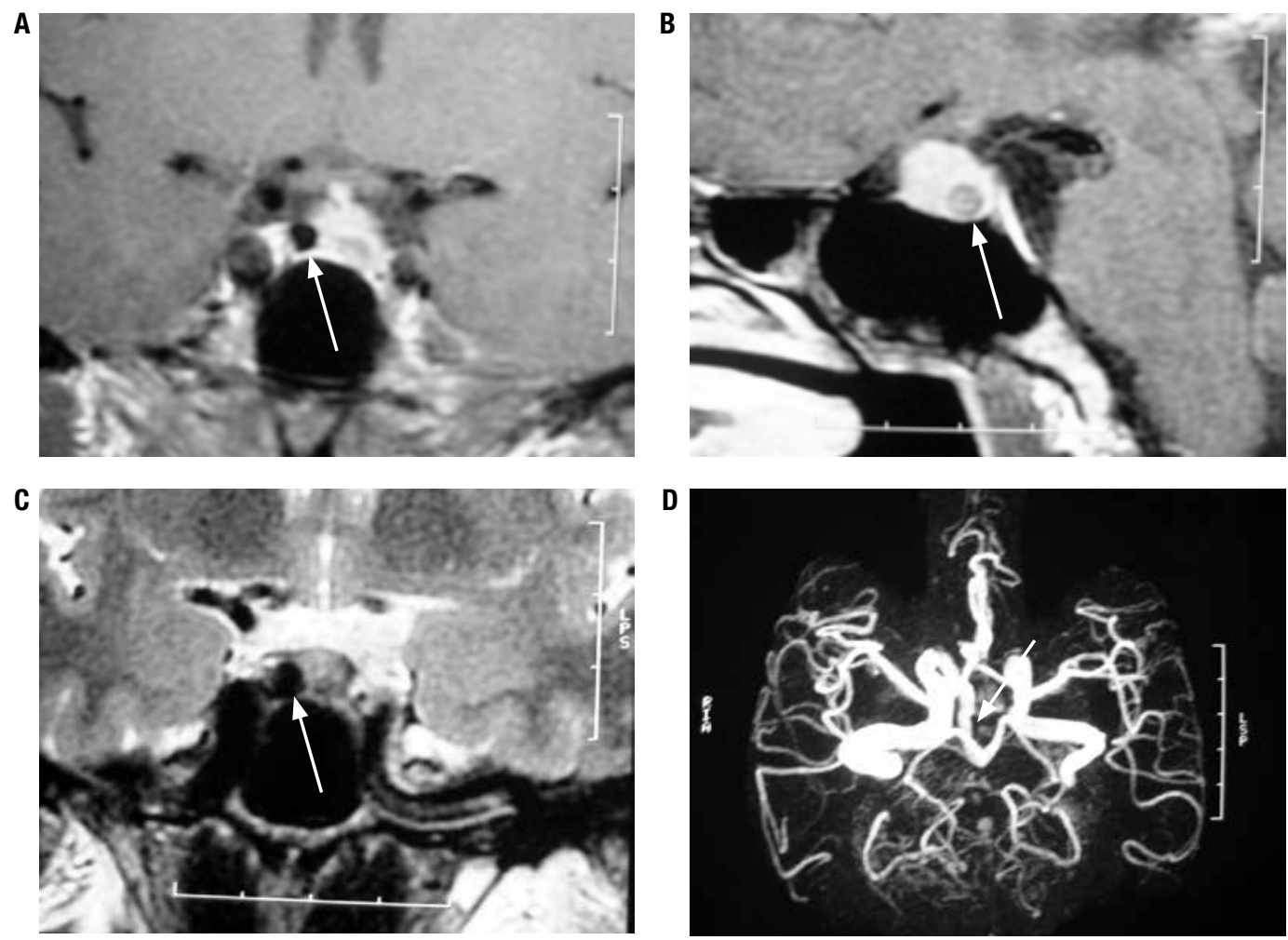

Figure 1. Pituitary MRI and cerebral vessel angio-MRI of patient 1 (2007).

(A) Coronal T1-weighted post-gadolinium MRI scans (intra-sellar trigeminal artery); (B) sagittal T1-weighted post-gadolinium MRI scans (pituitary adenoma of $7 \mathrm{~mm}$ of maximum diameter); (C) coronal T2-weighted (intra-sellar trigeminal artery); (D) cerebral vessels angio-MRI (trigeminal artery).

Upon our admission in December 2008, she presented with a minor headache, regular menses and the absence of galactorrhea using cabergoline $0.5 \mathrm{mg} /$ two weeks. She had no history of pregnancy. Upon her physical exam, she weighed $79.5 \mathrm{~kg}$, with a BMI $30.7 \mathrm{~kg} / \mathrm{m}^{2}$, abdominal circumference of $100 \mathrm{~cm}$, no galactorrhea and no other symptoms. Hormonal exams showed no alterations with a normal PRL $(11.8 \mathrm{ng} / \mathrm{mL}, \mathrm{R}:<25)$ and IGFl: $117 \mathrm{ng} / \mathrm{mL}$ (R: 101-267). Pituitary MRI (March 2009) (Figures 2A and 2D) showed a small low signal area in the anterior portion of the pituitary gland with a diameter of $6 \mathrm{~mm}$ suggestive of microadenoma and another well delimited, rounded lesion inside the pituitary gland, similar to a vessel (Figures $2 \mathrm{~B}, 2 \mathrm{C}$ and 2E). Her cabergoline use was stopped. Upon followup, the PRL became slighted elevated $(38.3 \mathrm{ng} / \mathrm{mL}, \mathrm{R}$ : $<25 \mathrm{ng} / \mathrm{mL}$ ) but no changes in the menses or any return of galactorrhea were noted. Macroprolactin levels were negative. Angio-MRI (June 2009) confirmed a left primitive PTA, a small dilatation of the adjacent artery and vertebrobasilar system hypoplasia (Figure 2F).

The Research Projects and Graduate Studies Commission and the Ethics Commission of our Institution approved this study, and all patients signed an informed consent form.

\section{DISCUSSION}

Vascular alterations, such as carotid artery aneurisms, are one differential diagnosis for sellar lesions, although they occur less frequently than pituitary adenomas. There are reports of aneurisms that mimic pituitary adenomas by causing hormonal changes, such as hypopituitarism and hyperprolactinemia, mostly due to mass effect (hypothalamic-pituitary disconnect) (13).

PTA arises in the region where the internal carotid artery enters the cavernous sinus. In approximately $50 \%$ of all cases of PTA, it runs lateral to the sella turcica. In the other $50 \%$ of cases, the PTA penetrates the sella turcica, runs along its own groove, perforates the dura near the clivus, and then joins the basilar artery. Thinning of the sellar floor and abnormalities of the dorsum sellar are frequent (14). In most cases, PTA is an incidental finding, but it presence may be associated with malformations, aneurysms or anomalies in the other blood vessels. Patients may be asymptomatic or present 
A

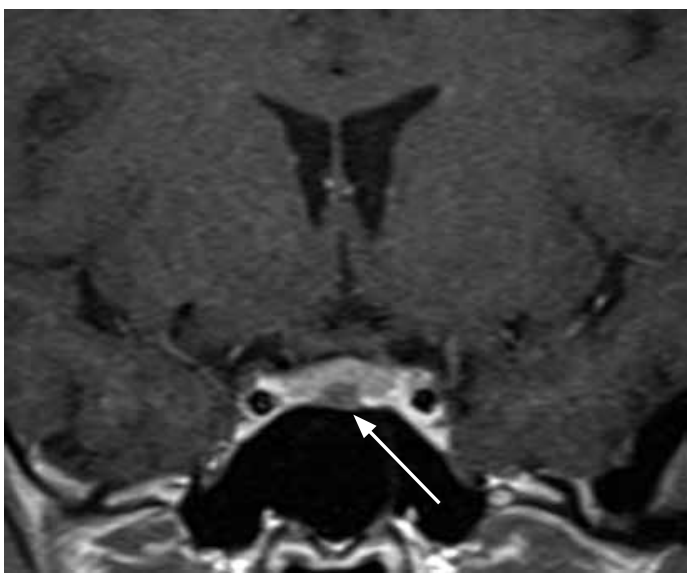

C

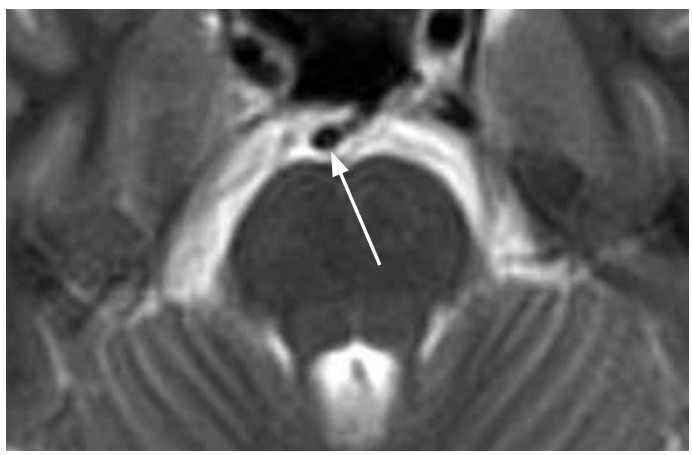

E

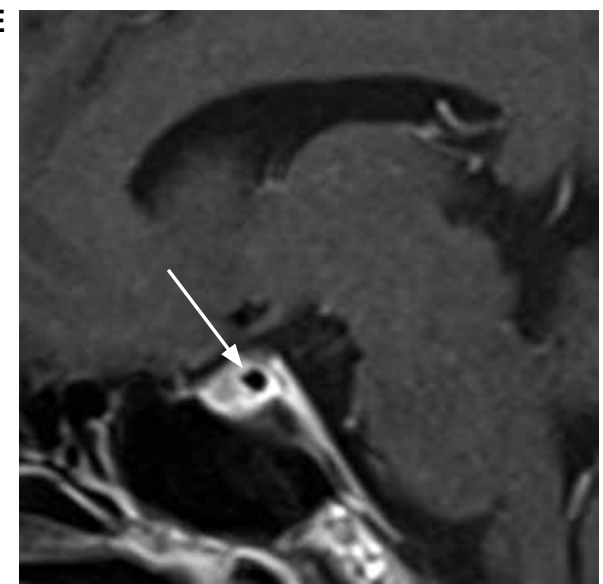

B

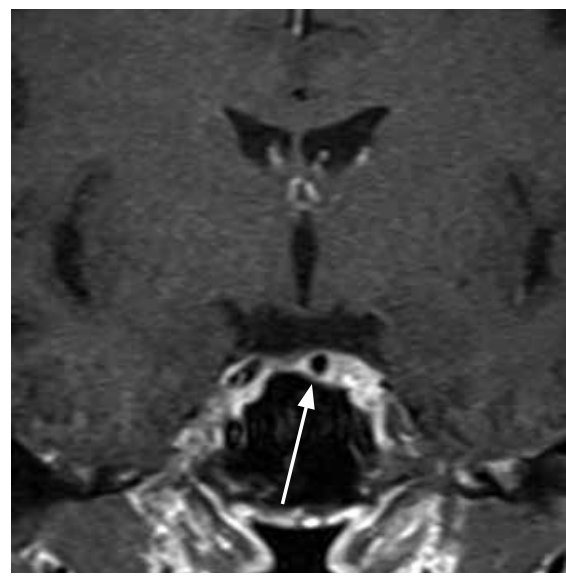

D
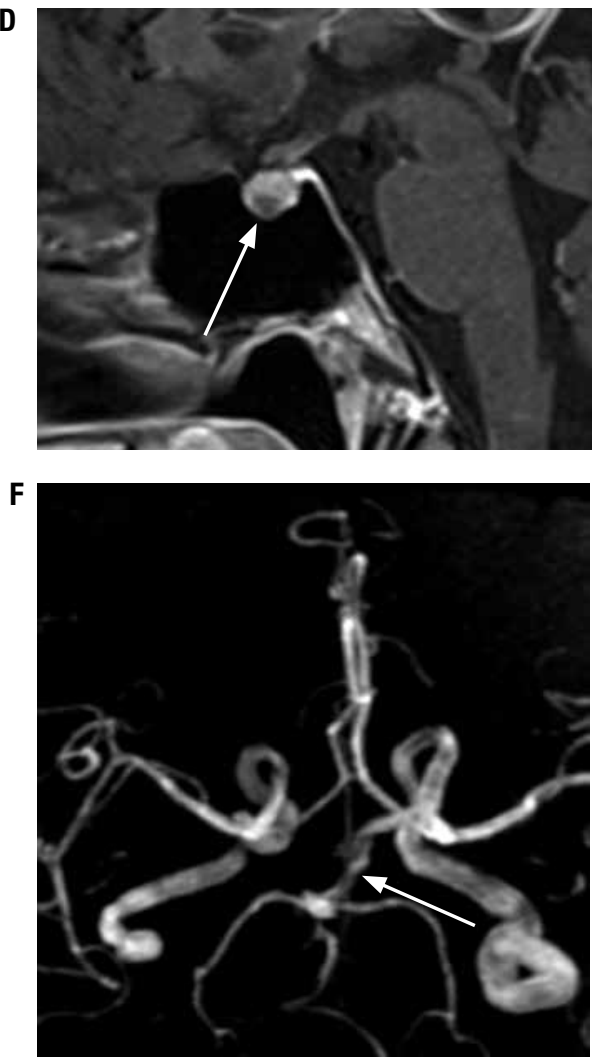

Figure 2. Pituitary MRI and cerebral vessels angio-MRI of patient 2 (2009).

(A) Coronal T1-weighted post-gadolinium MRI scans (median hipointensity: pituitary adenoma, $6 \mathrm{~mm}$ of maximum diameter); (B) coronal T1-weighted postgadolinium MRI scans (intra-sellar trigeminal artery); (C) axial T2- weighted (intra-sellar trigeminal artery); (D) sagittal T1-weighted post-gadolinium (hipointensity: pituitary adenoma); (E) sagittal T1-weighted post-gadolinium (intra-sellar trigeminal artery); and (F) cerebral vessels angio-MRI (trigeminal artery).

symptoms due to the flow of their posterior circulation or carotid microembolizations from the posterior circulation. In addition to these symptoms, PTA can cause trigeminal neuralgia $(3,5)$.

In 1989, the first two cases of intrasellar PTA associated with pituitary adenoma were described $(8,9)$, one of them due to Cushing's disease and macroadenoma (8). A third case was reported in 1991. A patient with a pituitary macroadenoma submitted to pituitary surgery, and PTA was discovered during the surgical procedure. The authors highlighted the importance of diagnosing this vascular lesion before the surgery to avoid serious complications (10).

Other pituitary adenomas have been described in 1996 in the small casuistic of eight PTA patients. This case was discovered during the investigation of several other clinical pictures (transient ischemic attack, stroke, headaches, intracerebral hemorrhage and venous mal- 
formation the scalp). One of the patients had a pituitary macroadenoma (11).

Finally, the $5^{\text {th }}$ case was reported in 2000. A 44-yearold patient with a non-functioning pituitary macroadenoma suffered tumoral apoplexy and submitted to pituitary neurosurgery. During the investigation, intrasellar PTA was identified in the left portion of the pituitary gland (12).

Both of our cases, although lacking surgical confirmation, are very suggestive of pituitary adenoma. In the first case, due to the uncharacteristic clinical picture but normal hormonal measurements and pituitary imaging, the diagnosis is most likely non-functioning pituitary microadenoma. In the second case, despite the lack of an initial MRI, the clinical history and hormonal analysis supported a diagnosis of microprolactinoma. In both cases, the diagnosis of intrasellar PTA was proposed by a rounded lesion in the coronal MRI suggesting a vascular lesion and was confirmed later by cerebral vessel angio-MRIs. Therefore, our cases are different from the majority of PTA reports associated with pituitary macroadenomas.

Two descriptions of PTA cases previously presented with hormonal changes. In one case, a diagnosis of PTA was made during the investigation of central precocious puberty (11). In 2001, a patient with PTA exhibited a compressive effect in the pituitary gland and pituitary stalk that caused hyperprolactinemia due to hypothalamic-pituitary disconnect (15).

Failure to recognize such anomalous vessels within the sella may lead to serious complications during transsphenoidal surgery. There are no specific findings on an MRI to make a differential diagnosis between PTA and pituitary microadenoma. However, a well-defined, rounded lesion similar to a vessel (observing the coronal section of the internal carotid artery in the cavernosus sinus) should lead to suspicions of PTA. The PTA can then be easily identified by MR angiography. Thus, angiography MRI or three-dimensional angiographyCT, which is less invasive than traditional angiography, should be performed preoperatively to avoid complications during surgery in suspected cases (11,16-18).

Therefore, although their occurrence is uncommon, a working knowledge of vascular lesions in the sella turcica or pituitary gland, such as a carotid internal artery aneurism or intrasellar PTA, is important for the differential diagnosis of pituitary lesions, especially of pituitary adenomas.

Acknowledgments: the authors have no acknowledgments to make for this article.
Disclosure: no potential conflict of interest relevant to this article was reported.

\section{REFERENCES}

1. Suttner N, Mura J, Tedeschi H, Ferreira MA, Wen HT, de Oliveira $\mathrm{E}$, et al. Persistent trigeminal artery: a unique anatomic specimen--analysis and therapeutic implications. Neurosurgery. 2000;47(2):428-33; discussion 433-4.

2. Salas E, Ziyal IM, Sekhar LN, Wright DC. Persistent trigeminal artery: an anatomic study. Neurosurgery. 1998;43(3):557-61; discussion 561-2.

3. Ballantyne ES, Page RD, Meaney JF, Nixon TE, Miles JB. Coexistent trigeminal neuralgia, hemifacial spasm, and hypertension: preoperative imaging of neurovascular compression. Case report. J Neurosurg. 1994;80(3):559-63.

4. Zingale A, Chiaramonte I, Mancuso P, Consoli V, Albanese V. Craniofacial pain and incomplete oculomotor palsy associated with ipsilateral primitive trigeminal artery. Case report. J Neurosurg Sci. 1993;37(4):251-5.

5. Conforti R, Parlato RS, De Paulis D, Cirillo M, Marrone V, Cirillo S, et al. Trigeminal neuralgia and persistent trigeminal artery. Neurol Sci. 2012;33(6):1455-8.

6. Nishio A, NishijimaY, Komiyama M, Hara M. Primitive trigeminal artery variant aneurysm treated with Guglielmi detachable coils-case report. Neurol Med Chir (Tokyo). 2001;41(9):446-9.

7. Kalidindi RS, Balen F, Hassan A, Al-Din A. Persistent trigeminal artery presenting as intermittent isolated sixth nerve palsy. Clin Radiol. 2005;60(4):515-9.

8. Lee KS, Kelly DL Jr. Intrasellar persistent trigeminal artery associated with a pituitary adenoma. Case report. J Neurosurg. 1989;70(2):271-3.

9. Salcman M. Persistent trigeminal artery and pituitary adenoma. J Neurosurg. 1989;71(2):301-2.

10. Szeifert G, Lányi F, Czirják S, Pásztor E. Persistent trigeminal artery associated with pituitary adenoma. Orv Hetil. 1991;132(26):1433-4.

11. Piotin M, Miralbés S, Cattin F, Marchal H, Amor-Sahli M, Moulin T, et al. MRI and MR angiography of persistent trigeminal artery. Neuroradiology. 1996;38(8):730-3.

12. AbeT, Fujita $\mathrm{S}$, Ozawa $\mathrm{H}$, Kawamura N, Shimazu M, lkeda $\mathrm{H}$, et al. Haemorrhagic nonsecreting pituitary adenoma associated with persistent primitive trigeminal artery. Acta Neurochir (Wien). 2000;142(12):1423-4.

13. Duarte FH, Machado MC, Lima JR, Salgado LR. Severe hyperprolactinemia associated with internal carotid artery aneurysm: differential diagnosis between prolactinoma and hypothalamic-pituitary disconnection. Arq Bras Endocrinol Metabol. 2008;52(7):1189-93.

14. Parkinson $D$, Shields $C B$. Persistent trigeminal artery: its relationship to the normal branches of the cavernous carotid. J Neurosurg. 1974;40(2):244-8.

15. Ekinci G, Baltacioğlu F, Kiliç T, Cimşit C, Akpinar I, Pamir N, et al. A rare cause of hyperprolactinemia: persistent trigeminal artery with stalk-section effect. Eur Radiol. 2001;11(4):648-50.

16. Schuierer G, Laub G, Huk WJ. MR angiography of the primitive trigeminal artery: report on two cases. AJNR Am J Neuroradiol. 1990;11(6):1131-2.

17. Meaney JF, Sallomi DF, Miles JB. Transhypophyseal primitive trigeminal artery: demonstration with MRA. J Comput Assist Tomogr. 1994;18(6):991-4.

18. Pereira LP, Nepomuceno LA, Coimbra PP, Oliveira Neto SR, Natal MR. Persistent trigeminal artery: angio-tomography and angiomagnetic resonance finding. Arq Neuropsiquiatr. 2009;67(3B):882-5. 